\title{
Effect of Visual Literacy on the Academic Achievements of Students in Computer Studies in Selected Secondary Schools in Enugu State, Nigeria
}

\author{
${ }^{* 1}$ Michael O. Edeh, ${ }^{2}$ Opeyemi R. Akindutire, ${ }^{3}$ Samuel G. Ugboaja, ${ }^{4}$ Stephen O. Ohwo, \\ ${ }^{5}$ Chukwudum $\mathrm{C}$. Umoke and ${ }^{6}$ Adesegun Osijirin \\ ${ }^{1}$ Department of Mathematics and Computer Science, Coal City University, Enugu, Nigeria \\ ${ }^{2}$ Department of Statistics, Ekiti State University, Ado-Ekiti, Nigeria \\ ${ }^{3}$ Department of Computer Science, Michael Okpara University of Agriculture, Umudike, Nigeria \\ ${ }^{4}$ Department of Computer Science, Delta State Polytechnic, Ogwashi, Nigeria \\ ${ }^{5}$ Department of Vocational and Technical Education, Alex Ekwueme Federal University, Abakaliki, Nigeria \\ ${ }^{6}$ Department of Applied Science, Federal College of Dental Technology and Therapy, Enugu, Nigeria \\ michael.edeh@ccu.edu.ng | roselynopeyemi@gmail.com | ugboaja.samuel@mouau.edu.ng | steveohwo@yahoo.com | \\ ukhcollins@gmail.com $\mid$ adesegunosijirin@fedcodtten.edu.ng
}

Received: 09-AUG-2021; Reviewed: 12-SEP-2021; Accepted: 29-SEP-2021 http://dx.doi.org/10.46792/fuoyejet.v6i3.683

\begin{abstract}
The study examines the effect of visual literacy on the academic achievement of students in Computer studies in selected secondary schools in Enugu State. A quasi-experimental design was used for the study and the sample consisted of one hundred (100) Senior Secondary School Two (SS2) students selected from both public and private secondary schools in Enugu State through stratified random sampling technique. The sample was divided into two major groups: experimental ( $n-50)$ and control group ( $n-50)$. The Experimental Group (EG) was taught using visual literacy materials, while the Control Group (CG) was taught without visual literacy. A pre-test and posttest of Computer Achievement Test (CAT) was administered to both groups before and after the treatment respectively. Data were later analyzed using frequencies, percentages, mean and standard deviation. While the hypotheses were tested using T-Test. The results showed that there was statistically significance difference between the academic achievements of students taught using visual literacy and those taught without visual literacy. The mean score (55.1400) of the EG was higher than that of the CG (49.3600), showing that students in the EG outperformed those in the $C G$ after the treatment. The findings further showed that there was a statistically significance difference between the academic achievements of male and female students who received the same visual literacy treatment. The mean score (56.0400) of female students in the EG was higher than that of their male counterparts (53.8800), showing that the female students performed better than the males. A statistically significant difference was also found in the mean scores of students from public and private schools who received the same visual literacy treatment. The students from the private school performed better than those from the public school. We conclude that visuals if properly integrated into the teaching and learning process could be a catalyst to stimulate students' critical thinking, comprehension and interpretation of concepts in Computer science.
\end{abstract}

Keywords- Academic Achievement, Animation, Computer studies, Multimedia, Secondary school, Visual literacy

\section{INTRODUCTION}

$\mathrm{T}$ he use of instructional materials such as visuals is very important in modern day reality education due to their potential to enhance students' understanding of concepts easily and clearly in the classroom. There is a universal recognition of the need to use visual media or technology in education (Aduwa-Ogiegbaen and Iyamu, 2005; Onyema, 2019; Odiase, and Okoli, 2016). The importance of visual literacy in contemporary culture is changing what it means to be literate in the 21st century (Hattwig et al, 2011). New visual technologies are changing human lives particularly teaching and learning practice whilst moving toward more effectively meeting the needs and preferences of individual learners (Ellen et al, 2002; Darley, Yussuff and Adenowo, 2021). Visual literacy is a set of abilities that enables an individual to effectively find, interpret, evaluate, use, and create images and visual media (Denise et al, 2012). Visuals are form of technology that could improve comprehension of concepts in Computer science class.

\section{${ }^{*}$ Corresponding Author}

Section B- ELECTRICAL/COMPUTER ENGINEERING \& COMPUTING SCIENCES Can be cited as:

Edeh M.O., Akindutire O.R., Ugboaja S.G., Ohwo S.O., Umoke C.C. and Osijirin A. (2021): "Effect of Visual Literacy on the Academic Achievements of Students in Computer Studies in Selected Secondary Schools in Enugu State, Nigeria", FUOYE Journal of Engineering and Technology (FUOYEJET), 6(3), 1520. http://dx.doi.org/10.46792/fuoyejet.v6i3.683
As a result of the internet penetration, big amount of unstructured visual data in form of images, and videos are being generated from the social media networking sites such as Twitter, Facebook and Google (Akinboro, Ogundoyin and Olusesi, 2021). The use of visual media in education is supported by previous research which shows that students today live in a visually rich, screenbased world and they regularly encounter and create meaning and knowledge through images and visual media (Brumberger, 2011; Onyema, 2019b).

Visual images are increasingly appearing in teaching and learning resources, delivered across a range of media in a variety of formats: digitally in Web-based materials and multimedia as well as in print and as transparencies (Ellen et al, 2002). Visuals are used by teachers and students to prepare academic presentations, slides, reports, handouts and to illustrate concepts in the classroom. The use of computer animation in teaching ensures more effective way of preparing students to carry out the task assigned to modern engineers (Krzysztof et al, 2015). Visual literacy skills equip a learner to understand and analyze the contextual, ethical, aesthetic, intellectual, and technical components involved in the production and use of visual materials (Hattwig et al, 2011). The use of visuals along with traditional methods of teaching can increase students' performance (Kay and Kletskin, 2012). Larry (2006) stated that visually literate individuals have an imaginative ability to see and 
understand the messages communicated with images, as well as to create, modify, and use visual cues and images. Students' knowledge, understanding, and ability to interpret, analyze, evaluate and critically engage with visual and digital texts are not automatic, and needs to be taught (Boyd, 2014).

David (2006) stated that there are concerns about the inability of students to express themselves visually, make effective arguments with visuals, synthesize concepts in their own visual products, develop aesthetically engaging presentations, and coordinate visuals with other information. Many concepts are abstract and may need additional visual representation for students to understand, thus the use of visual literacy can aid comprehension in learning process (Cook, 2011). Using images, videos and other diagrams are better for understanding than long verbal explanations (Chen and Sun, 2012). The use of animations has been shown to be beneficial in science lessons and student-centered learning (Soika, 2007; Onyema et al, 2019a).

Onasanya and Omosewo (2010) carried out a study on the effects of using standard instructional materials, including visual aids on secondary school students' academic performance in Physics in Nigeria. Their findings showed that students taught with visuals outperformed those who were not. Their study focused on Physics unlike the current study that focuses on computer studies and also their study was carried out since year 2010 while this study was done in 2021. Similarly, a study by Katrin et al (2010), which assessed the importance of animation as a visual method in Computer science pedagogy showed that understanding visualized material is easier than to read information from the paper-based instruction. Learning can be enhanced with images, video and sound. For example, direct instruction can feature animations and videos of processes or situations (Michelle, 2013).

According to the report of United States Institute for the Advancement of Research in Education (2003), using videos or animations in the classroom is a step in the right direction towards implementing and taking advantage of the available technology to enrich teaching and learning. The use of videos, diagrams, pictures and animations could help students understand difficult concepts and enhance their interests in a course (Onyema et al, 2019b). Visuals can strengthen understanding, especially of abstract processes that are hard for learners to envision in their mind (Ferreira et al, 2011), it can help students to develop their minds, memorize knowledge and to familiarize themselves with the schemes of solving technical problems (Krzysztof et al., 2015).

Computer Science is an important course that explores the entire computer architecture and how its different components are intertwined. There is a growing demand for Computer science professionals due to the increasing use of technology across different disciplines. Computer science as a course is being taught as Computer studies or Information Technology at the secondary school level in Nigeria. Computer science curriculum is often designed to equip learners with the skills and tools they need, to analyze, design and implement computer hardware and software and to adapt to digital era or knowledge-based society.

However, there have been recent concerns about poor performance of students in computer science courses, particularly at the secondary school level. Poor academic achievements of learners in Computer science have attracted attention of scholars, parents, policy makers and planners (Meenu, 2016). This has necessitated calls by stakeholders for more researches on possible ways to improve students' interests and performance in Computer science and other sciences. More visuals are used now by millenials than ever before, in the form of charts, graphs, animations and pictures (Brumberger, 2011). Connecting to students' activities outside of class, such as watching animations or using other visuals like Youtube videos or pictures, can also help engage students and keep them interested in a given course (Michelle, 2013; Onyema et al, 2020).

Unfortunately, most studies have been silent on the effects of visual literacy on students' academic achievements in Computer science. Also, visual literacy has received little attention in secondary school curricula as most secondary schools seem to focus primarily on the reading, writing and verbal forms of communication and neglect the form and quality of a student's visual skills in favor of his or her verbal skills (Yeh and Lohr, 2010). This has created a gap in literature which the present study attempted to solve. Many secondary school teachers seem to ignore or are not aware of the potential of visual literacy in improving teaching excellence and learning outcomes. Thus, this study examined the effectiveness of visual literacy materials in helping to address the problem of poor performance of secondary school students in computer studies using a designed Computer Achievement Test. This is with a view to create more awareness about the effectiveness of visual literacy materials in improving learning outcome.

The main objective of this study was to investigate the effects of visual literacy on the academic achievements of students in Computer studies in selected secondary schools in Enugu State, Nigeria. While the specific objectives were to examine whether there is any significant difference between the academic achievements of students taught using visual literacy materials and those taught without visual literacy materials. Also, to examine whether there is any significant difference between the academic achievements of male and female students taught using visual literacy materials. Lastly, to ascertain whether there is any significant difference between the academic achievements of students from public and private schools taught using visual literacy materials.

\section{Methodology}

A quasi-experimental design was used for the study and the sample consisted of one hundred (100) Senior Secondary School Two (SS2) students selected from one public and two private secondary schools in Enugu State using stratified random sampling technique. The sample was divided into two major groups: experimental group 
(n-50) and control group (n-50). The Experimental Group (EG) was taught using visual literacy materials (videos, animations, images, drawings etc), while the control group (CG) was taught using the normal conventional classroom method (without visual literacy). A pre-test and Post-test of Computer Achievement Test (CAT) was administered to both groups before and after the treatment respectively. Data were later analyzed using frequencies, percentages, mean and standard deviation. While the hypotheses were tested using T-Test.

\subsection{VALIDITY AND RELIABILITY OF INSTRUMENT}

Two senior Computer science teachers who are teaching Computer studies/ ICT at the Senior secondary school level were asked to check the content and construct validity of the Computer Achievement Test. They were asked to check if the test addressed the Senior Secondary School Two (SS2) content of the computer studies/ ICT curriculum, and whether the language of the test is within the cognitive level of the students. Their suggestions were taken into consideration in the construction of the test. Also, a pilot study involving 20 SS2 students was carried out to determine the reliability of the instrument. The participants in the pilot study did not take part in the final study. Cronbach's Alpha was used to measure the internal consistency and the reliability coefficient of 0.76 was found which indicated that the instrument was reliable.

\section{RESULTS}

\subsection{DEMOGRAPHIC INFORMATION OF PARTICIPANTS}

Table 1 shows that $50 \%$ of the respondents were females while $50 \%$ were males i.e. $\left(\mathrm{N}_{\mathrm{m}}=50, \mathrm{~N}_{\mathrm{f}}=50\right)$. This implies that there was gender equality among the participants. The number of males and females were the same.

Table 1. Distribution of Participants by Gender

\begin{tabular}{ccc}
\hline Gender & Frequency & Percentage \\
\hline Male & 50 & 50 \\
Female & 50 & 50 \\
Total & 100 & $100 \%$ \\
\hline
\end{tabular}

\subsection{AChieVement Test Results}

A Pre-test and Post-test was conducted to assess the impact that visual literacy usage had on students' academic achievements, and the differences in their academic achievements based on gender and school type after the treatment. The results are given below:

\subsubsection{Pre-test Result}

From the results presented in Table 2, the mean scores of both groups only differ by 0.42 (i.e., $34.8400-34.4200$ ). At 0.05 level of significance and 98 degrees of freedom, the p-value of 0.736 indicates that there is no statistically significant difference in the sample groups which took part in the study. Hence, both groups before the treatment came from the same population.
Table 2. Sample Pre-test

\begin{tabular}{|c|c|c|c|c|c|c|c|c|}
\hline \multirow{2}{*}{$\begin{array}{c}\text { Pre- } \\
\text { test }\end{array}$} & Grouping & $\mathbf{N}$ & Mean & $\mathbf{d f}$ & $\mathbf{t}$ & $\begin{array}{c}\text { Sig. } \\
\mathbf{( 2 -} \\
\text { tailed } \\
\mathbf{~}\end{array}$ & $\begin{array}{c}\text { Std. } \\
\mathbf{D e} \\
\mathbf{v}\end{array}$ & $\begin{array}{c}\text { Std. } \\
\text { Error } \\
\text { Mean }\end{array}$ \\
\cline { 2 - 8 } & $\begin{array}{c}\text { Grp } \\
\text { Experiment } \\
\text { al Grp }\end{array}$ & 50 & 34.84 & 98 & 0.338 & 0.736 & $\begin{array}{c}6.72 \\
904\end{array}$ & $\begin{array}{c}0.951 \\
63\end{array}$ \\
\hline
\end{tabular}

\subsubsection{Post-test Results}

Research Question One: What effect does the use of Visual Literacy Materials have on Students' Academic Achievement in Computer Studies?

Table 3 shows the mean score of 49.36 and a standard deviation of 4.61 for the students taught without visual literacy materials (Control Group). While those who were taught with visual literacy materials achieved more with a mean score of 55.14 and a standard deviation of 3.29. This implies that students who were taught with visual literacy materials achieved more than those taught without visual literacy materials (Control Group). This finding is consistent with that of Eick and King (2012) and Gill (2011) which revealed that students who participated in their studies found the use of visuals embedded in their lectures to be useful in their learning. It is also in agreement with the findings of Chen and Sun (2012) and Harwood \& McMahon (1997) which revealed that students who were taught using visuals (integrated video media, video based and interactive multimedia) during their studies had significant improvements in their academic achievements and learning attitudes afterwards.

Table 3. Group Statistics of Academic Achievements of Students taught using Visual Literacy materials

\begin{tabular}{|c|c|c|c|c|c|}
\hline & Grouping & $\mathbf{N}$ & Mean & $\begin{array}{c}\text { Std. } \\
\text { Dev. }\end{array}$ & $\begin{array}{c}\text { Std. Error } \\
\text { Mean }\end{array}$ \\
\hline \multirow{2}{*}{$\begin{array}{c}\text { Post- } \\
\text { test }\end{array}$} & \begin{tabular}{c} 
Control Grp \\
\cline { 2 - 6 }
\end{tabular} & 50 & 49.3600 & 4.60594 & 0.65138 \\
\hline al Grp & 50 & 55.1400 & 3.28888 & 0.46512 \\
\hline
\end{tabular}

Research Question Two: Is there any Significance Difference between the Academic Achievements of Male and Female Students taught using Visual Literacy?

Table 4 shows the mean score of 56.04 and a standard deviation of 3.05 for female students taught using visual literacy materials, as against that of their male counterparts who were exposed to the same treatment but obtained a lower mean score of 53.88 and a standard deviation of 3.17. This implies that the female students achieved more than their male counterparts after being exposed to the same visual literacy treatment by a mean difference of 2.16 .

Table 4. Statistics of Academic Achievements of Male and Female students taught using Visual Literacy materials

\begin{tabular}{|c|c|c|c|c|}
\hline Gender & $\mathbf{N}$ & Mean & Std. Dev. & Std. Error Mean \\
\hline Female & 25 & 56.0400 & 3.04795 & 0.60959 \\
\hline Male & 25 & 53.8800 & 3.16649 & 0.63330 \\
\hline
\end{tabular}


Research Question Three: Is there any Significant Difference between the Academic Achievements of Students in Public and Private schools taught Using Visual Literacy?

Table 5 shows the mean score of 51.80 and a standard deviation of 5.10 for public school students exposed to Visual Literacy, and that of Private school students who received the same treatment, but obtained a higher mean score of 56.16 and a standard deviation of 3.02. This implies that private school students outperformed the public-school students after their exposure to Visual Literacy treatment by a mean difference of 4.36 in favour of the private school students.

Table 5. Statistics of the Academic Achievements of students in Public and Private schools taught using Visual Literacy

\begin{tabular}{|c|c|c|c|c|c|}
\hline & School Grp & N & Mean & $\begin{array}{c}\text { Std. } \\
\text { Deviation }\end{array}$ & $\begin{array}{c}\text { Std. } \\
\text { Error } \\
\text { Mean }\end{array}$ \\
\hline \multirow{2}{*}{$\begin{array}{c}\text { School } \\
\text { Type }\end{array}$} & $\begin{array}{c}\text { Public } \\
\text { School }\end{array}$ & 25 & 51.8000 & 5.09902 & 1.01980 \\
\cline { 2 - 6 } & $\begin{array}{c}\text { Private } \\
\text { School }\end{array}$ & 25 & 56.1600 & 3.02324 & 0.60465 \\
\hline
\end{tabular}

\subsection{Testing OF Hypotheses}

\subsubsection{Hypothesis One}

Ho1: There is no Significant Difference Between the Academic Achievements of Students taught using Visual Literacy and those taught without Visual Literacy materials.

The result presented in Table 6 indicates a statistically significant difference in the mean scores of both groups at 0.05 level of significance and 98 degrees of freedom. The p-value of 0.00 does not favour Ho1, therefore the study found a statistically significant difference between students taught with Visual literacy materials (experimental Gp) and those taught without visual literacy materials (Control Gp). The difference however, favours the experimental group which had a higher mean score of 55.14 as against the mean of 49.36 by the Control group. This shows that the experimental group outperformed the control group after the treatment. Therefore, the null hypothesis is rejected. This is consistent with the finding of Harwood and McMahon (1997), which revealed that visual literacy had positive effects on the academic achievements and learning attitudes of high school Chemistry students after their exposure to visual literacy material (video series). Similarly, A study conducted by Gill (2011) also revealed that the use of visual literacy increased students' engagement and achievements in learning.

\begin{tabular}{|c|c|c|c|c|c|c|c|c|}
\hline \multirow{3}{*}{$\begin{array}{c}\text { Post- } \\
\text { test }\end{array}$} & $\begin{array}{c}\text { Groupin } \\
\mathrm{g}\end{array}$ & $\mathbf{N}$ & Mean & df & t & $\begin{array}{l}\text { Sig. } \\
(2- \\
\text { tail } \\
\text { ed) }\end{array}$ & $\begin{array}{l}\text { Std. } \\
\text { Dev. }\end{array}$ & $\begin{array}{l}\text { Std. } \\
\text { Error } \\
\text { Mean }\end{array}$ \\
\hline & $\begin{array}{l}\text { Control } \\
\text { Grp } \\
\text { (Conven } \\
\text { tional } \\
\text { Method) }\end{array}$ & 50 & 49.36 & 98 & -7.221 & 0.0 & 4.60594 & 0.65138 \\
\hline & $\begin{array}{c}\text { Experim } \\
\text { ental } \\
\text { Grp }\end{array}$ & 50 & 55.14 & & & & 3.28888 & 0.46512 \\
\hline
\end{tabular}

\subsubsection{Hypothesis Two}

Ho2: There is no significant difference between the academic achievements of male and female students taught using visual literacy materials.

Table 7 indicates a statistically significant difference in the mean scores of male and female students after their exposure to the visual literacy treatment with a p-value of 0.018 at 48 degrees of freedom against $\alpha=0.05$. Table 7 showed a mean score of 56.04 in favour of the female students which is higher than that of the male students who had a mean score of 53.88. The implication of this is that the female students had higher academic achievements than their male counterparts after their exposure to the visual literacy treatment. Therefore, the null hypothesis is rejected. This is consistent with the finding of Sayid and Milad (2011), which showed that differences exist in the cognitive-motivational functioning of boys and girls in the academic environment, and the girls have a more adaptive approach to learning tasks after exposure to new learning pattern.

\begin{tabular}{|c|c|c|c|c|c|c|c|c|}
\hline & $\begin{array}{c}\text { Gende } \\
\mathbf{r}\end{array}$ & $\mathbf{N}$ & Mean & df & $t$ & $\begin{array}{c}\text { Sig. } \\
(2- \\
\text { tailed } \\
\quad\end{array}$ & $\begin{array}{l}\text { Std. } \\
\text { Dev }\end{array}$ & $\begin{array}{c}\text { Std. } \\
\text { Error } \\
\text { Mean }\end{array}$ \\
\hline \multirow{2}{*}{$\begin{array}{c}\text { Post- } \\
\text { test }\end{array}$} & $\begin{array}{c}\text { Femal } \\
\text { e }\end{array}$ & 25 & 56.04 & 48 & 2.457 & 0.018 & $\begin{array}{l}3.04 \\
795 \\
\end{array}$ & 0.60959 \\
\hline & Male & 25 & 53.88 & & & & $\begin{array}{l}3.16 \\
649\end{array}$ & 0.63330 \\
\hline
\end{tabular}

\subsubsection{Hypothesis Three}

Hoз: There is no significant difference between the academic achievements of public and private school students taught using visual literacy materials.

Table 8. Analysis of Hypothesis Three

\begin{tabular}{|c|c|c|c|c|c|c|c|c|}
\hline & $\begin{array}{c}\text { School } \\
\text { Type }\end{array}$ & $\mathbf{N}$ & $\begin{array}{c}\text { Mea } \\
\mathbf{n}\end{array}$ & $\mathbf{d f}$ & $\mathbf{t}$ & $\begin{array}{c}\text { Sig. } \\
\mathbf{( 2 -} \\
\text { tailed } \\
\mathbf{~}\end{array}$ & $\begin{array}{c}\text { Std. } \\
\text { Dev }\end{array}$ & $\begin{array}{c}\text { Std. } \\
\text { Error } \\
\text { Mean }\end{array}$ \\
\hline \multirow{2}{*}{$\begin{array}{c}\text { Pos } \\
\mathrm{t}-\end{array}$} & $\begin{array}{c}\text { Public } \\
\text { test }\end{array}$ & 25 & $\begin{array}{c}51.80 \\
00\end{array}$ & 48 & -3.678 & 0.001 & $\begin{array}{c}5.09 \\
902\end{array}$ & 1.01980 \\
\cline { 2 - 9 } & $\begin{array}{c}\text { Private } \\
\text { School }\end{array}$ & 25 & $\begin{array}{c}56.16 \\
00\end{array}$ & & & & 3.02 & 0.60465 \\
\hline
\end{tabular}


Table 8 indicates a statistically significant difference in the mean scores of public and private school students taught using visual literacy materials, with a p-value of 0.001 at 48 degrees of freedom against $\alpha=0.05$. Table 8 shows a higher mean score of 56.16 in favour of the private school students as against that of public-school students who had a mean score of 51.80 after their exposure to the same visual literacy treatment. This implies that private school students performed better than their counterparts from the public schools after their exposure to the same visual literacy treatment. Therefore, the null hypothesis is rejected. This finding is consistent with that of Samuel (2017), which revealed that students from private schools often perform much better in academics than those in public schools. However, this finding is inconsistent with that of David and Kathleen (2006), which showed that junior secondary students in public schools performed better than those from private school due to higher quality inputs at junior secondary school.

\section{Discussion OF FINDINGS}

The findings of this study shows that there was statistically significance difference between the academic achievements of students taught using visual literacy and those taught without visual literacy. The mean score (55.14) of the experimental group was higher than that of the control group (49.36), showing that students in the experimental group outperformed those in the control group after the treatment. Also, the findings showed a statistically significance difference between the academic achievements of male and female students who received the same visual literacy treatment together in the experimental group. The mean score (56.04) of the female students in the experimental group was higher than that of their male counterparts (53.88), showing that the female students performed better than the males after been taught with visual literacy materials. Furthermore, a statistically significant difference was also found in the mean score (51.80) of public-school students and private school students (56.16) who received the same visual literacy treatment together in the experimental group. The students from the private school had a higher mean score which indicated that they performed better than those from the public school.

From our findings, we deduce that students found the use of visuals (videos, pictures, diagrams, animations, and drawings etc) very helpful in improving their understanding of concepts in Computer studies which had positive effects on their academic achievements after the treatment. The findings of this study are consistent with that of Box \& Cochenour (1995), which revealed that visual literacy is an important skill for improving the teaching and learning process, and Michelle (2013), which found a higher achievement among Biology students who were taught with visual literacy materials. Similarly, our findings agreed with that of Tillmann (2012), which showed that the use of visual literacy materials for teaching help students to learn decipher, understand and communicate with images and enhance their learning outcomes. While, Huilcapi-Collantes et al (2020) also indicated that visual literacy is essential for improving visual communication skills of students and teachers. This study establishes that the use of visuals in the classroom has the potential to improve students' performance, productivity in learning and understanding of perceived difficult concepts in class. With visual literacy, students can be better positioned to interact more with educational materials, understand concepts and then derive meanings to solve a given problem. Therefore, teachers should embrace emerging visual technologies to improve the quality of their teachings.

\section{Conclusions}

The study highlights the effectiveness of visuals (images, videos, pictures, animations, and drawings etc) in enhancing the learning outcomes of students in Computer science. Students who were taught with visuals showed significant improvements in their academic achievements after the treatment. Also, our finding indicates that teaching with visuals has positive effects on students' understanding of concepts and performance in Computer science, and could help change their negative perceptions towards any aspects of the course. Thus, visuals if properly integrated into the classroom could be a catalyst to stimulate interactive learning, critical thinking, students' comprehension and interpretation of concepts in the classroom.

There is need for more researches to determine how visual technologies can be used to improve students' interest in Computer programming and other aspects of Computer science that students often perceive as being difficult. Also, researchers can also examine the role of visual literacy in development of e-contents for e-learning activities.

\section{REFERENCES}

Aduwa-Ogiegbaen, S.E. and Iyamu, E.O.S. (2005). Using Information and Communication Technology in Secondary Schools in Nigeria: Problems and Prospects. Educational Technology \& Society, vol. 8, pp. 104-112.

Akinboro S., Ogundoyin I. K. and Olusesi A.T. (2021): Big Data Analysis of Facebook Users Personality Recognition using Map Reduce Back Propagation Neural Networks, FUOYE Journal of Engineering and Technology, Vol 6, no 2, pp 47-52. http://dx.doi.org/10.46792/fuoyejet.v6i2.594

Box, C. A., \& Cochenour, J. (1995). Visual literacy: What do prospective teachers need to know? Imagery and Visual Literacy: Selected Readings from the Annual Conference of the International Visual Literacy Association (26th, Tempe, Arizona,October 12-16

Boyd, D. (2014). It's Complicated. International Journal of Communication, vol. 8, pp. 2783-2786.

Brumberger, E. (2011). Visual Literacy and the digital native: An examination of the Millennial Learner. Journal of Visual Literacy, Vol. 30, no 1, pp 19-46

Chen, C., \& Sun, Y. (2012). Assessing the effects of different multimedia materials on emotions and learning performance for visual and verbal style learners. Computers \& Edu, Vol. 59, no 4, pp 1273-1285

Cook, M. (2011). Teachers' Use of Visual Representations in the Science Classroom. Science Edu. International, Vol. 22 no. 3, pp. 175-184.

Darley O., Yussuff A.I.O. and Adenowo A.A. (2021): Investigation into Rain Attenuation Prediction Models at Locations in Lagos Using Remote Sensing, FUOYE Journal of Engineering and Technology, Vol. 6 no. 2, pp 19-24. http://dx.doi.org/10.46792/fuoyejet.v6i2.626 
David, G. (2006). Using Digital Images in Teaching and Learning: Perspectives from Liberal Arts Institutions, Academic Commons. Retrieved August, 2021 from: http://www.academiccommons.com.

David, N. and Kathleen, B. (2006). The Effect of School Type on Academic Achievement: Evidence from Indonesia. The Journal of Human Resources, Vol.41 no 3, pp 529-557.

Eick, C., \& King, D. T. (2012). Nonscience Majors' Perceptions on the Use of YouTube Video to Support Learning in an Integrated Science Lecture. Journal of College Science Teaching, Vol. 42 no 1, pp 26-30.

Ferreira, C., Baptista, M., \& Arroio, A. (2011). Visual Tools in Teaching Learning Sequences for Science Education. Problems of Education in the 21st Century, Vol. 79, pp 3748-58.

Gill, R. (2011). Effective Strategies for Engaging Students in LargeLecture, Nonmajors Science Courses. Journal of College Science Teaching, Vol. 41 no 2, pp 14-21.

Harwood, W. S., \& McMahon, M. M. (1997). Effects of integrated video media on student achievement and attitudes in high school chemistry. Journal of Research in Science Teaching, Vol. 34 no 6, pp 617-631.

Hattwig D., Bussert K., Medaille A., Burgess J. (2013). Visual Literacy Standards in Higher Education: New Opportunities for Libraries and Student Learning, Libraries and the Academy. The Johns Hopkins University Press, Baltimore, Vol. 13 no. 1, pp 61-89.

Huilcapi-Collantes, C., Hernández Martín, A., \& Hernández-Ramos, J. P. (2020). The Effect of a Blended Learning Course of Visual Literacy for in-Service Teachers. J. of Info. Tech. Edu. Res., Vol. 19, pp. 131-166. https://doi.org/10.28945/4533

Katrin, S., Priit, R \& Rain, M. (2010). The Importance of Animation as a Visual Method in Learning Chemistry. Proc. of Fourth Int. Conference on Concept Mapping Viña del Mar, Chile, 2010.

Kay, R., \& Kletskin, I. (2012). Evaluating the Use of Problem-Based Video Podcasts to Teach Mathematics in Higher Education. Computers \& Education, Vol. 59 no 2, pp 619-627.

Krzysztof, D; Marcin, B; Magdalena, P; Agnieszka, J. (2015). The Role of Computer Animation in Teaching Technical Subjects. Advances in Science and Tech. Research Journal, Vol. 9 no 28, pp 134-138. DOI:10.12913/22998624/60801

Larry, J. (2006). The Sea Change Before Us. Educause Review, 41 (2), 73.

Meenu, D. (2016). Factors Affecting the Academic Achievement: A Study of Elementary School Students of NCR Delhi, India. J. of Education and Practice, Vol. 7no 4, pp $70-74$.

Michelle, J.M.P (2013). Effects of Visual Media on Achievement and Attitude in a Secondary Biology Classroom. A Master's Research Project Presented to the Faculty of the Patton College of Education and Human Services, Ohio University.

Odiase, P.O and Okoli, G.C (2016). Electro-Mechanical Based Automated Whiteboard Wiper. FUOYE Journal of Engineering and Technology, vol. 1 no 1, pp 90-94. DOI: http://dx.doi.org/10.46792/fuoyejet.v1i1.18

Onasanya B.I. \& Omosewo, O. O. (2010). Effect of using improvised and standard instructional materials on Secondary School Students' Academic Performance in Physics in Ilorin, Nigeria. Singapore Journal of Scientific Research, 1(1), 68-76.

Onyema, E.M, Sharma, A, Nwafor, C.E, Fyneface, A.G, Sen, S, Edeh, E.C. (2020). Impact of Emerging Technologies on the Job Performance of Educators in Selected Tertiary Institutions in Nigeria. The Journal of Computer Science and its Applications, Vol. 27 no 1, pp 52-62. https://dx.doi.org/10.4314/jcsia.v27i1.4

Onyema, E. M. (2019b). Integration of Emerging Technologies in Teaching and Learning Process in Nigeria: the challenges. Central Asian Journal of Mathematical Theory and Computer Sciences, 1(August), vol. 1, pp 35-39.
Onyema, E.M. (2019a). Opportunities and challenges of the use of mobile phone technology in teaching and learning in Nigeria-A Review. Int. Journal of Research in Engineering and Innovation, Vol. 3 no 6, pp 352-358. https://doi.org/10.36037/ijrei.2019.3601.

Onyema, E.M; Deborah, E. C., Alsayed, A. O., Noorulhasan, Q., \& Sanober, S. (2019b). Online Discussion Forum as a Tool for Interactive Learning and Communication. International Journal of Recent Techn and Engineering, Vol. 8 no 4, pp 4852-4859. https://doi.org/10.35940/ijrte.d8062.118419.

Onyema, E.M; Udeze, O.A., \& Deborah, E. C. (2019a). Potentials of Mobile Technologies in Enhancing the Effectiveness of Inquirybased learning. Int. Journal of Education (IJE), Vol. 2, no 1, pp 125. https://doi.org/10.5121/IJE.2019.1421.

Samuel, K. R. (2017). A Comparison of Academic Performance Between Public and Private Secondary Schools in Wareng District, Kenya. British J. of Education, Vol. 5 no, pp 11, 58-67.

Sayid, D.G. and Milad, K.K. (2011). Gender differences in factors affecting academic performance of high school students Procedia - Social and Behavioral Sciences, 15, 1040-1045. https://doi.org/10.1016/j.sbspro.2011.03.236.

Sims E., O'Leary R., Cook J., Butland G. (2002). Visual literacy: what is it and do we need it to use learning technologies effectively. Proceedings of the 19th Annual Conference of the Australian Society for Computers in Tertiary Education (ASCILITE), Auckland, New Zealand.

Tillmann, A. (2012), "What We See and Why It Matters: How Competency in Visual Literacy can Enhance Student Learning. Honours Projects. Retrieved August 2021 from http://digitalcommons.iwu.edu/education_honproj/9

Yeh, H. \& Lohr, L. (2010). Towards evidence of visual literacy: Assessing pre-service teachers' perceptions of instructional visuals. J. of Visual Literacy, Vol. 29, no 2, pp 183-197. 